\title{
New patients, new disorders, new drugs and the rise of prescriptions
}

\author{
Luis Camara Pestana \\ From $1^{\text {st }}$ International Congress on Neurobiology and Clinical Psychopharmacology and European \\ Psychiatric Association Conference on Treatment Guidance \\ Thessaloniki, Greece. 19-22 November 2009
}

The rise of prescription of psychotropic drugs is a major healthcare problem namely in Psychiatry. The reason of the rise is not clear and many questions remain unanswered. Furthermore, we have more patients, more drugs, more resistant and demanding patients and more polypharmacy. Inappropriate prescribing and lack of rational is not uncommon and prescribing education is also a main concern. Although, the use of guidelines for treatment could make clinical work easier they differ in their objectives and contents. We will discuss the doctor's capacity to make more diagnosis, the problematic of out of label prescriptions and the potential of abuse of some medication and the implications in the rise of prescription. The continuous update and training in clinical psychopharmacology and joint decision-making process between clinicians will allow a rational approach to treatment.

Published: 22 April 2010

doi:10.1186/1744-859X-9-S1-S71

Cite this article as: Pestana: New patients, new disorders, new drugs and the rise of prescriptions. Annals of General Psychiatry 2010 9(Suppl 1): S71.
Portuguese Association of Biological Psychiatry and Portuguese Authority of Drugs and Pharmacy, Portugal

○ 2009 Pestana; licensee BioMed Central Ltd.
Submit your next manuscript to BioMed Central and take full advantage of:

- Convenient online submission

- Thorough peer review

- No space constraints or color figure charges

- Immediate publication on acceptance

- Inclusion in PubMed, CAS, Scopus and Google Scholar

- Research which is freely available for redistribution

Submit your manuscript at www.biomedcentral.com/submit 